\title{
ANALISIS KEUNTUNGAN DAN TITIK IMPAS TERNAK AYAM KAMPUNG SUPER DAN AYAM BROILER DI DESA BANGUN HARJO BUAY MADANG TIMUR OKU TIMUR
}

\author{
(Iman Sulaiman)
}

\begin{abstract}
The objectives of this research are to: (1) To analyze the cost, income and income of chicken and chicken cattle in Bangu Harjo Village, Buay Madang Timur District, OKU Timur Regency, (2) To analyze whether broiler and joper cattle cultivated in Bangun Harjo Village, Buay Madang Timur Sub-district, OKU Timur Regency is beneficial, (3) To analyze break even point of broiler and joper livestock business in Bangun Harjo Village, Buay Madang Timur District, OKU Timur Regency. This research has been conducted in Bangun Harjo Village, Buay Madang Timur District, East OKU Regency. Site selection is done purposively with the consideration that in the village is able to represent from the existing population and have the criteria of research plan. Bangun Harjo village is a village whose majority population live as farmers and there are some farmers who seek the cultivation of super chicken (joper) and broiler (broiler). The study was conducted in June 2015. The study found that the total production cost incurred in the poultry livestock business in Bangun Harjo Village in one production process amounted to Rp 13,963,744, the average revenue was $R p 22,920,000$ so that income Received amounted to $R p$ 8,956,256. The value of $R$ / $C$ ratio is 1.64 indicating that the chicken livestock business is profitable. The total production cost incurred in the broiler business in Bangun Harjo Village in one production process is $R p$ 30,609,006, the average revenue is $R p$ 54,676,250, so the income received is $R p$ 24,067,224. The value of $R / C$ ratio is 1.79 indicates that the business of broiler livestock is profitable and BEP value of livestock production volume of chicken joper is 349 head, while the value of BEP price is Rp 24.569 / Tail and BEP value of broiler chicken

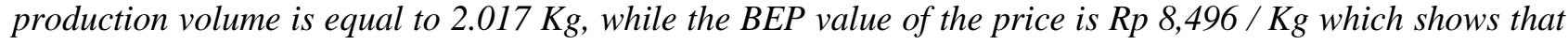
the business of chicken and broiler cattle in Bangun Harjo Village is feasible financially.
\end{abstract}

Key Words : Chicken Breeding, Feasibility Analysis, Break-Even Analysis and Income.

\section{PENDAHULUAN}

\section{A. Latar Belakang}

Pembangunan peternakan pada era globalisasi bertujuan untuk mewujudkan masyarakat yang sehat, produktif dan kreatif melalui peternakan yang tangguh berbasis sumber daya lokal. Iklim perdagangan global yang sudah mulai terasa saat ini semakin memungkinkan produk ayam lokal Indonesia masuk ke pasar luar negeri. Kenyataan tersebut menggambarkan bahwa usaha peternakan ayam sangat prospektif baik dilihat dari pasar dalam negeri maupun luar negeri. Dilihat dari segi peluang pasar pengembangan agribisnis peternakan memiliki prospek yang baik khususnya dalam memenuhi kebutuhan domestik yang semakin meningkat. Potensi agribisnis peternakan tersebut didukung juga oleh keberadaan dan kepemilikan ayam lokal yang mulai berkembang dikalangan masyarakat khususnya masyarakat pedesaan (Simatupang et al. 2004).

Kebutuhan manusia akan protein hewani sangat besar, rata-rata konsumsi negara maju dan berkembang lebih dari $20 \mathrm{~kg}$ perkapita pertahun. Singapura dan Malaysia sendiri rata-rata konsumsi daging masyarakatnya adalah $28 \mathrm{~kg}$ perkapita pertahun dan $36 \mathrm{~kg}$ perkapita pertahun, jauh dari Indonesia yang rata-rata konsumsi daging masyarakatnya hanya $4,11 \mathrm{~kg}$ perkapita pertahun. Konsumsi protein hewani berkaitan dengan tingkat intelektualitas dan perkembangan seseorang (Anonim, 2011).

Sebenarnya untuk mendapatkan protein yang berkualitas, orang dapat mengkonsumsi sumber protein nabati, di samping sumber protein hewani, terutama dari jenis kacang-kacangan, seperti kacang kedelai, kacang hijau, dan kacang tanah. Akan tetapi, umumnya protein yang berasal dari sumber protein nabati hanya mengandung beberapa jenis asam amino tertentu yang tidak lengkap. Sumber protein hewani biasanya lebih lengkap kandungan asam aminonya. (Sarwono, 2005).

Keunggulan protein hewani membuat industri atau usaha peternakan memiliki potensi yang besar untuk berkembang, dikarenakan konsumsi daging masyarakat Indonesia yang masih rendah masih dapat ditingkatkan. Usaha peternakan diIndonesia sangat bermacam-macam jenis hewan yang diusahakan, diantaranya sapi, kambing, kuda, kerbau, babi, ayam, unggas 
lainnya dan daging lainnya. Hanya daging sapi, kambing dan ayamlah yang sering dikonsumsi oleh masyarakat, namun diantara ketiga daging tersebut daging ayamlah yang paling banyak di konsumsi oleh masyarakat Indonesia. Daging ayam menjadi primadona untuk konsumsi masyarakat dikarenakan harganya yang relatif murah dibandingkan daging sapi dan kambing (Anonim, 2011).

Tabel 1. Konsumsi Rata-rata per Kapita Setahun Daging Ayam Ras (Broiler) dan Ayam Buras di Indonesia, 2009-2013.

\begin{tabular}{cccc}
\hline No & Tahun & Ayam Ras Pedaging $(\mathrm{Kg})$ & Ayam Buras $(\mathrm{Kg})$ \\
\hline 1. & 2009 & 3,076 & 0.521 \\
2. & 2010 & 3,546 & 0.626 \\
3. & 2011 & 3,650 & 0.626 \\
4. & 2012 & 3,494 & 0.521 \\
5. & 2013 & 3,650 & 0.469 \\
\hline
\end{tabular}

Sumber: Survei Sosial Ekonomi Nasional, 2009 2013.

Daging ayam merupakan salah satu bahan konsumsi masyarakat yang cukup tinggi permintaannya. Ayam kampung super membuka peluang usaha baru yang sangat menjanjikan karena permintaan akan daging ayam kampung meningkat dengan signifikan.

Ayam kampung merupakan ayam lokal di Indonesia yang kehidupannya sudah lekat dengan masyarakat, ayam kampung juga dikenal dengan sebutan ayam buras (bukan ras), atau ayam sayur. Penampilan ayam kampung sangat beragam, begitu pula sifat genetiknya, penyebarannya sangat luas karena populasi ayam buras dijumpai di kota maupun desa. Potensinya patut dikembangkan untuk meningkatkan gizi masyarakat dan menaikkan pendapatan keluarga (Bakrie et al., 2003).

Ayam kampung mempunyai kelebihan pada daya adaptasi tinggi karena mampu menyesuaikan diri dengan berbagai situasi, kondisi lingkungan dan perubahan iklim serta cuaca setempat. Ayam kampung memiliki bentuk badan yang kompak dan susunan otot yang baik. Bentuk jari kaki tidak begitu panjang, tetapi kuat dan ramping, kukunya tajam dan sangat kuat mengais tanah. Ayam kampung penyebarannya secara merata dari dataran rendah sampai dataran tinggi. Kondisi yang ada terkait dengan masalah utama dalam pengembangan ayam kampung adalah rendahnya produktifitas. Salah satu faktor penyebabnya adalah sistem pemeliharaan yang masih bersifat tradisional, jumlah pakan yang diberikan belum mencukupi dan pemberian pakan yang belum mengacu kepada kaidah ilmu nutrisi (Gunawan, 2002).

Ayam kampung merupakan salah satu komoditas jenis ayam yang banyak dipelihara oleh sebagian besar masyarakat Indonesia dan merupakan ternak unggas yang banyak diminati oleh konsumen, permintaan pasar akan daging ayam kampung pun terus meningkat, akan tetapi produksi ayam kampung yang lambat mengakibatkan kurangnya pasokan daging ayam kampung. Usaha peternakan yang dapat dilakukan untuk memperoleh produktivitas ayam kampung yang baik adalah dengan cara melakukan program pemuliaan guna meningkatkan mutu genetiknya melalui persilangan. Saat ini berkembang persilangan antara betina ayam ras dengan pejantan ayam kampung untuk mendapatkan produktivitas yang lebih baik dari ayam kampung dengan nama ayam kampung super. Ayam kampung super merupakan hasil persilangan antara ayam kampung dengan ayam ras (Aman, 2011).

Ayam kampung super atau ayam lokal pedaging unggul yang merupakan hasil persilangan antara ayam kampung dengan ras jenis petelur. Ayam hasil persilangan tersebut memiliki perumbuhan yang lebih cepat dibanding ayam lokal, sehingga orang menyebutnya dengan ayam kampung super (Yaman, 2010). Lebih lanjut dinyatakan bahwa ayam kampung super dalam usia dua bulan beratnya bisa mencapai $1,5 \mathrm{~kg}$, umur 45 - 75 hari sudah siap dikonsumsi, hal tersebut yang membedakan dengan ayam kampung asli yang umumnya baru bisa dipanen setelah $3-6$ bulan. Adanya teknologi baru, kini hadir ayam kampung super atau ayam jawa super. Ternak ayam kampung super secara nyata lebih menjanjikan karena dalam masa pemeliharaan hanya membutuhkan waktu 50-60 hari untuk panen.

Menurut (Yaman, 2010), perbedaan yang paling signifikan antara ayam kampung umumnya dengan ayam kampung super terlihat pada kemampuan menghasilkan daging, terutama pada organ tubuh bagian dada dan bagian paha, seperti ayam pedaging unggul lainnya, perkembangan kedua jenis tipe otot tersebut menunjukan bahwa ayam kampung super memiliki sifat dengan jenis ayam pedaging lainnya. Ayam kampung super mempunyai sifat dwiguna yaitu ayam sebagai penghasil telur dan daging. Ayam kampung super pedaging waktu pemeliharaan 2-3 bulan sudah siap panen. Adanya teknologi baru, kini hadir ayam kampung super atau ayam jawa super. 
Ternak ayam kampung super secara nyata lebih menjanjikan karena dalam masa pemeliharaan hanya membutuhkan waktu 50-60 hari untuk panen.

Ayam broiler adalah istilah yang dipakai untuk menyebut ayam hasil budidaya teknologi yang memiliki karakter ekonomi dengan ciri khas pertumbuhan cepat, penghasil daging dengan konversi pakan irit dan siap potong pada usia relatif muda. Pada umumnya ayam broiler siap dipotong pada usia 35-45 hari (Murtidjo, 1994).

Ayam pedaging atau broiler adalah ayam jantan atau betina muda yang di bawah umur 8 minggu ketika dijual dengan bobot tubuh tertentu mempunyai pertumbuhan yang cepat serta mempunyai dada lebar dengan timbunan daging yang banyak. Jadi ayam yang pertumbuhannya cepat itulah yang dimasukkan dalam kategori ayam pedaging atau broiler (Rasyaf, 2006).

Ayam broiler memiliki kelebihan dan kelemahan. Kelebihannya adalah dagingnya empuk, ukuran badan besar, bentuk dada lebar, padat dan berisi, efisiensi terhadap pakan cukup tinggi, sebagian besar dari pakan diubah menjadi daging dan pertambahan bobot badan sangat cepat. Sedangkan kelemahannya adalah memerlukan pemeliharaan secara intensif dan cermat, relatif lebih peka terhadap suatu infeksi penyakit dan sulit beradaptasi (Murtidjo, 1994).

Tabel 2. Produksi Daging Ayam Ras Pedaging (Broiler) dan Ayam Buras Provinsi Sumatera Selatan, 2010-2014.

\begin{tabular}{|c|c|c|c|}
\hline No & Tahun & $\begin{array}{c}\text { Ayam Pedaging } \\
\text { (Ton) }\end{array}$ & $\begin{array}{c}\text { Ayam Buras } \\
\text { (Ton) }\end{array}$ \\
\hline 1 & 2010 & 31.000 & 6.024 \\
\hline 2 & 2011 & 28.185 & 6.823 \\
\hline 3 & 2012 & 30.447 & 7.068 \\
\hline 4 & 2013 & 29.997 & 8.961 \\
\hline 5 & $2014^{*}$ & 32.579 & 9.344 \\
\hline
\end{tabular}

Sumber : Direktorat Jenderal Peternakan

Keterangan : *) Angka Sementara

Desa Bangun Harjo merupakan salah satu desa di Kecamatan Buay Madang Timur Kabupeten OKU Timur yang sebagian besar penduduknya bekerja sebagai petani padi sawah. Selain sebagai petani di Desa Bangun Harjo juga terdapat sebagian masyarakat yang mengembangkan peternakan ayam pedaging (ayam broiler), ayam kampung dan baru-baru ini terdapat sebagian warga yang mulai merintis usaha peternakan ayam kampung super (ayam joper). Menurut sebagian warga yang mengembangkan usaha peternakan ayam pedaging (broiler) dirasakan cukup menguntungkan dengan masa pemeliharaan yang cukup singkat maka ayam broiler telah dapat dipasarkan. Sebagian warga juga telah ada yang mulai merintis usaha peternakan ayam kampung super atau ayam joper. Mereka mengatakan bahwa ayam joper tersebut memiliki perumbuhan yang lebih cepat dibanding ayam kampung biasa, dalam usia dua bulan beratnya bisa mencapai 1,5 $\mathrm{kg}$, umur 50-60 hari sudah siap dikonsumsi dan harga jual daging ayam joper lebih mahal dibandingkan ayam broiler.

Permintaan daging ayam joper juga semakin meningkat khususnya bagi masyarakat yang tidak menyukai daging ayam broiler atau ayam potong maka ayam joper menjadi alternatif pilihan pengganti. Pemasaran ayam joper juga cukup mudah terutama untuk melayani permintaan dari pedagang serta restoran-restoran atau rumah makan yang berada di sekitar Kecamatan Belitang.

\section{B. Rumusan Masalah}

1. Berapa besar biaya penerimaan dan pendapatan usaha ternak ayam broiler dan joper di Desa Bangun Harjo Kecamatan Buay Madang Timur Kabupaten OKU Timur.

2. Apakah ternak ayam broiler dan joper yang diusahakan di Desa Bangun Harjo Kecamatan Buay Madang Timur Kabupaten OKU Timur menguntungkan.

3. Bagaimana titik impas (break even point) dari usaha ternak ayam broiler dan joper di Desa Bangun Harjo Kecamatan Buay Madang Timur Kabupaten OKU Timur.

\section{Tujuan dan Kegunaan}

1. Untuk menganalisis biaya, penerimaan dan pendapatan usaha ternak ayam joper dan ayam broiler di Desa Bangu Harjo Kecamatan Buay Madang Timur Kabupaten OKU Timur.

2. Untuk menganalisis apakah ternak ayam broiler dan joper yang diusahakan di Desa Bangun Harjo Kecamatan Buay Madang Timur Kabupaten OKU Timur menguntungkan.

3. Untuk menganalisis titik impas (break even point) dari usaha ternak ayam broiler dan joper di Desa Bangun Harjo Kecamatan Buay Madang Timur Kabupaten OKU Timur. 
D. Model Pendekatan

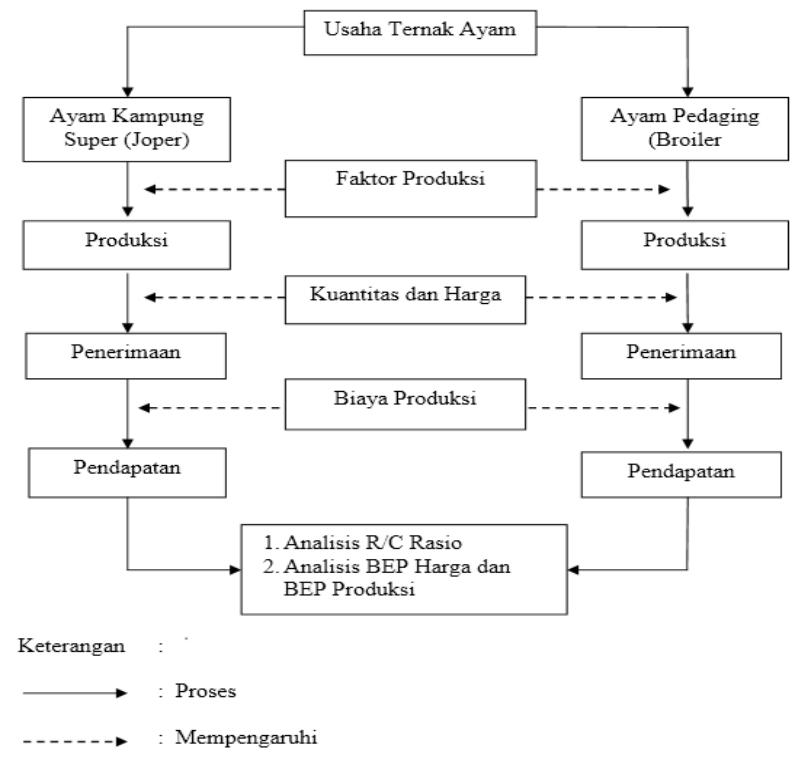

Gambar 1. Model pendekatan penelitian secara diagramatik.

\section{METODOLOGI PENELITIAN}

\section{A. Tempat dan Waktu}

Penelitian ini telah dilaksanakan di Desa Bangun Harjo Kecamatan Buay Madang Timur Kabupaten OKU Timur. Pemilihan lokasi dilakukan secara sengaja (purposive) dengan pertimbangan bahwa di desa tersebut mampu mewakili dari populasi yang ada dan memiliki kriteria rencana penelitian. Desa Bangun Harjo merupakan desa yang mayoritas penduduknya bermata pencaharian sebagai petani dan terdapat sebagian petani yang mengusahakan budidaya ayam kampung super (joper) dan ayam pedaging (broiler). Penelitian telah dilaksanakan pada Bulan Juni 2015.

\section{B. Metode Penelitian}

Metode penelitian yang digunakan dalam penelitian ini adalah metode survei yang bertujuan untuk mendapatkan gambaran yang ada di lapangan dengan benar. Menurut Nazir (2011), metode survei adalah penyelidikan yang dilakukan untuk memperoleh fakta-fakta dan gejala-gejala yang ada dan mencari keterangan secara faktual dari suatu kelompok atau suatu daerah tertentu.

\section{Metode Penarikan Contoh}

Metode penarikan contoh yang digunakan adalah dengan metode sensus, yaitu dengan menjadikan semua populasi sebagai anggota sampel. Reponden peternak yang diambil berjumlah 13 reponden dari 13 populasi, masingmasing berjumlah 5 orang peternak ayam joper dari 5 populai dan 8 peternak ayam broiler dari 8 populasi.

\section{Metode Pengolahan Data}

Data yang diperoleh, baik data primer maupun data sekunder dalam penelitian ini dianalisis secara kuantitatif. Analisis data yang dilakukan meliputi analisis terhadap biaya-biaya yang dikeluarkan, penerimaan yang diperoleh, dan pendapatan usaha ternak ayam joper dan broiler. Pengolahan data dilakukan dengan menggunakan komputer Microsoft Excel.

Untuk menjawab tujuan penelitian yang pertama yaitu untuk mengetahui besarnya biaya, penerimaaan dan pendapatan budidaya ayam joper dan ayam broiler dihitung dengan menggunakan rumus secara matematis dapat dinyatakan sebagai berikut :

1) Untuk mengetahui biaya produksi dengan rumus (Soekartawi, 2002):

$\mathrm{TC}=\mathrm{FC}+\mathrm{VC}$

Dimana :

$\mathrm{TC}=$ Total Cost $/$ Biaya Total Produksi (Rp/Proses)

$\mathrm{FC}=$ Fixed Cost / Biaya Tetap (Rp/Proses)

$\mathrm{VC}=$ Variabel Cost / Biaya Variabel (Rp/Proses)

2) Untuk mengetahui penerimaan digunakan rumus (Soekartawi, 2002):

$\mathrm{TR}=$ Py $\mathrm{x} Y$

Dimana :

$\mathrm{TR}=$ Total Revenue $/$ Total Penerimaan (Rp/Proses)

Py = Price / Harga Jual $(\mathrm{Rp} / \mathrm{Kg})$

$\mathrm{Y}=$ Yield $/$ Hasil Produksi (Kg/Proses)

3) Untuk menghitung pendapatan, digunakan rumus (Soekartawi, 2002):

$\mathrm{I}=\mathrm{TR}-\mathrm{TC}$

Dimana :

$\mathrm{I}=$ Income / Pendapatan (Rp/Proses)

$\mathrm{TR}=$ Total Revenue $/$ Penerimaan $(\mathrm{Rp} /$ Proses $)$

$\mathrm{TC}=$ Total Cost $/$ Total Biaya Produksi (Rp/Proses)

4) $\mathrm{R} / \mathrm{C}$ ratio dihitung dengan menggunakan rumus (Sokartawi, 2002):

$\mathrm{R}=\mathrm{Py} . \mathrm{Y}$

$\mathrm{C}=\mathrm{FC}+\mathrm{VC}$

$\mathrm{R} / \mathrm{C}$ Rasio $=\frac{(\mathrm{Py} \cdot \mathrm{Y})}{(\mathrm{FC}+\mathrm{VC})}$

Dimana :

$\mathrm{R}=$ Revenue / Penerimaan ( $\mathrm{Rp} / \mathrm{proses})$ 
$\mathrm{Py}=$ Price $/$ Harga produk $(\mathrm{Rp} / \mathrm{kotak})$

$\mathrm{Y}=$ Yield $/$ Jumlah Produk (Kotak/proses)

$\mathrm{C}=$ Cost / Biaya Total (Rp/proses)

$\mathrm{FC}=$ Fix Cost / Biaya Tetap (Rp/proses)

$\mathrm{VC}=$ Variabel Cost / Biaya Variabel (Rp/proses)

Dengan ketentuan :

$\begin{array}{lll}\mathrm{R} / \mathrm{C} \text { Ratio } & >\text { Berarti usahatani } \\ \text { menguntungkan } & \\ \mathrm{R} / \mathrm{C} \text { Ratio }< & \begin{array}{l}1 \text { Berarti usahatani tidak } \\ \text { menguntungkan (rugi) }\end{array}\end{array}$

Untuk menjawab tujuan penelitian yang kedua yaitu untuk menganalisis manakah yang lebih menguntungkan antara usaha budidaya ayam Joper dan ayam broiler di Desa Bangun Harjo Kecamatan Buay Madang Timur Kabupaten OKU Timur maka digunakan analisis Break Event Point (BEP) Produksi dan BEP Harga :

a) Break Even Point (BEP) volume produksi menggambarkan produksi minimal yang harus dihasilkan dalam usaha agar tidak mengalami kerugian. Menurut Suratiyah (2006), rumus perhitungan BEP produksi adalah :

$$
\text { BEP Produksi }=\frac{\mathrm{FC}}{\mathrm{P}-\mathrm{AVC}}
$$

$\mathrm{FC}=$ Fix Cost $/$ Biaya Tetap (Rp/Proses)

$\mathrm{P}=$ Price / Harga Jual ( $\mathrm{Rp} / \mathrm{Kg})$

$\mathrm{AVC}=$ Average Variabel Cost / Biaya Variabel perunit $(\mathrm{Rp} / \mathrm{Kg})$

b) Break Even Point harga menggambarkan total penerimaan produk dengan kuantitas produk pada saat BEP. Dengan kata lain adalah harga minimal yang harus dihasilkan agar usaha tidak mengalami kerugian. Adapun rumus BEP Harga adalah (Suratiyah, 2006) :

$$
\begin{aligned}
& \text { BEP Harga }=\frac{\mathrm{TC}}{\mathrm{Y}} \\
& \mathrm{TC}=\text { Total Cost / Biaya Total (Rp/Proses) } \\
& \mathrm{Y}=\text { Yield / Harga ( } \mathrm{Rp} / \mathrm{Kg})
\end{aligned}
$$

\section{HASIL DAN PEMBAHASAN}

\section{A. Analisis Biaya Usaha Peternakan Ayam Joper dan Ayam Broiler}

Biaya dalam kegiatan usaha dikeluarkan oleh responden dengan tujuan untuk menghasilkan pendapatan yang tinggi bagi usaha yang dikerjakan, dengan mengeluarkan biaya maka pelaku usaha mengharapkan pendapatan yang setinggi-tingginya melalui peningkatan produksi. Biaya dalam kegiatan usaha terdiri dari biaya tetap (fixed cost) dan biaya variabel (variabel cost).

Biaya tetap (fixed cost) adalah biaya yang relatif tetap jumlahnya dan harus dikeluarkan walaupun produk yang dihasilkan banyak atau sedikit. Biaya tidak tetap (variable cost) adalah biaya yang sifatnya berubah-ubah tergantung dari besar kecilnya produksi yang dihasilkan. Dalam hasil penelitian yang dikelompokkan ke dalam biaya tetap di antaranya adalah biaya sewa tanah dan biaya penyusutan alat. Sedangkan untuk biaya variabel terdiri dari biaya pembelian sarana produksi pertanian dan biaya tenaga kerja. Berikut ini merupakan komponen biaya yang dikeluarkan oleh peternak ayam joper dan ayam broiler di Desa Bangun Harjo Kecamatan Buay Madang Timur OKU Timur :

\section{Biaya Tetap (Fixed Cost)}

Biaya tetap yang digunakan oleh responden oleh peternak ayam joper dan ayam broiler di Desa Bangun HarjoKecamatan Buay Madang Timur OKU Timur diantaranya meliputi biaya sewa lahan dan biaya penyusutan peralatan yang dapat dilihat pada tabel berikut :

Tabel 3. Rata-rata Biaya Tetap Peternak Ayam Joper Dan Ayam Broiler di Desa Bangun Harjo, 2015.

\begin{tabular}{llcc}
\hline \multirow{2}{*}{ No } & Komponen Biaya & \multicolumn{2}{c}{ Peternak } \\
\cline { 3 - 4 } & & 400.000 & $\begin{array}{c}\text { Ayam Broiler } \\
\text { (Rp/Proses) }\end{array}$ \\
\hline 1. & Sewa Lahan & 432.544 & 337.500 \\
2. & Penyusutan Alat & 832.544 & 446.881 \\
\hline & Jumlah Biaya Tetap & & 784.381
\end{tabular}

Sumber: Olahan Data Primer, 2015.

Berdasarkan data di atas diketahui bahwa biaya sewa lahan peternak ayam joper di Desa Bangun Harjo, dalam satu kali proses produksi (2 bulan) adalah sebesar $\mathrm{Rp} 400.000$ dan rata-rata biaya penyusutan alat yang digunakan dalam satu kali proses produksi adalah sebesar Rp 432.544. Biaya tetap peternak ayam joper di Desa Bangun Harjo yang terdiri dari biaya sewa lahan dan biaya penyusutan peralatan dalam satu kali proses produksi adalah sebesar Rp 832.544.

Biaya sewa lahan peternak ayam broiler di Desa Bangun Harjo, dalam satu kali proses produksi (1 bulan) adalah sebesar Rp 337.000 dan rata-rata biaya penyusutan alat yang digunakan dalam satu kali proses produksi adalah sebesar Rp 446.881 Biaya tetap peternak ayam broiler di Desa Bangun Harjo yang terdiri dari biaya sewa lahan dan biaya penyusutan peralatan dalam satu kali proses produksi adalah sebesar Rp 784.381. Biaya tetap reponden peternak ayam joper lebih 
besar dibandingkan biaya tetap peternak ayam broiler dikarenakan proses produksinya lebih lama sehingga akan meningkatkan nilai biaya sewa dan biaya penyuutan peralatan.

\section{Biaya Variabel (Variabel Cost)}

Biaya variabel adalah biaya yang digunakan dalam kegiatan usaha dan biasanya habis dalam satu kali proses produksi. Biaya variabel yang digunakan dalam usaha ternak ayam joper dan ayam broiler di Desa Bangun Harjo terdiri atas biaya pembelian sarana produksi dan biaya tenaga kerja. Adapun besarnya biaya variabel yang dikeluarkan oleh peternak ayam joper dan ayam broiler yang terdiri dari biaya saprodi dan biaya tenaga kerja dapat dilihat pada tabel berikut :

Tabel 4. Rata-rata Biaya Variabel Peternak Ayam Joper dan Ayam Broiler di Desa Bangun Harjo, 2015.

\begin{tabular}{llcc}
\hline \multirow{2}{*}{ No } & \multirow{2}{*}{ Komponen Biaya } & \multicolumn{2}{c}{ Peternak } \\
\cline { 3 - 4 } & & Ayam Joper (Rp/Proses) & $\begin{array}{c}\text { Ayam Broiler } \\
\text { (Rp/Proses) }\end{array}$ \\
\hline 1. & Biaya Saprodi & 9.211 .200 & 26.562 .125 \\
2. & Biaya Tenaga Kerja & 3.920 .000 & 3.262 .500 \\
\hline & Jumlah Biaya Variabel & 13.131 .200 & 29.824 .625
\end{tabular}

Sumber: Olahan Data Primer, 2015.

Berdasarkan data di atas diketahui bahwa biaya saprodi peternak ayam joper maupunayam broiler di Desa Bangun Harjo digunakan untuk membeli bibit ayam joper, biaya pakan, vitamin dan obat-abatan, biaya listrik dan air bersih. Besarnya biaya saprodi peternak ayam joper dalam satu kali proses produksi ( 2 bulan) adalah sebesar Rp 9.211.200 dan rata-rata biaya tenaga kerja adalah sebesar Rp 3.920.000 sehingga diperoleh biaya variabel usaha ternak ayam joper dalam satu kali proses produksi adalah sebesar Rp 13.131.200.

Berdasarkan data pada tabel 4 di atas juga dapat diketahui bahwa besarnya biaya saprodi peternak ayam broiler dalam satu kali proses produksi (1 bulan) adalah sebesar Rp 26.562.125 dan rata-rata biaya tenaga kerja adalah sebesar $\mathrm{Rp}$ 3.262.500 sehingga diperoleh biaya variabel usaha ternak ayam broiler dalam satu kali proses produksi adalah sebesar Rp 29.824.625. Besarnya biaya variabel usaha ternak ayam broiler lebih besar daripada biaya variabel usaha ternak ayam joper.

\section{Biaya Total (Total Cost)}

Biaya total dalam kegiatan usaha ternak ayam joper maupun ayam broiler di Desa Bangun Harjo terdiri dari biaya tetap ditambah dengan biaya variabel. Besarnya biaya total yang dikeluarkan oleh responden peternak ayam joper dan ayam broiler di Desa Bangun Harjo pada tabel berikut :
Tabel 5. Rata-rata Biaya Total Usaha Ternak Joper dan Ayam Broiler di Desa Bangun Harjo, 2015.

\begin{tabular}{cccc}
\hline \multirow{2}{*}{ No } & \multirow{2}{*}{ Komponen Biaya } & \multicolumn{2}{c}{ Peternak } \\
\cline { 3 - 4 } & & $\begin{array}{c}\text { Ayam Joper } \\
\text { (Rp/Proses) }\end{array}$ & $\begin{array}{c}\text { Ayam Broiler } \\
\text { (Rp/Proses) }\end{array}$ \\
\hline 1. & Biaya Tetap & $\mathbf{8 3 2 . 5 4 4}$ & $\mathbf{7 8 4 . 3 8 1}$ \\
& a. Sewa Lahan & 400.000 & 337.500 \\
& b. Penyusutan Peralatan & 432.544 & 446.881 \\
2. Biaya Variabel & $\mathbf{1 3 . 1 3 1 . 2 0 0}$ & $\mathbf{2 9 . 8 2 4 . 6 2 5}$ \\
& a. Biaya Saprodi & 9.211 .200 & 26.562 .125 \\
& b. Biaya Tenaga Kerja & 3.920 .000 & 3.262 .500 \\
\hline 3. Jumlah Biaya Total & $\mathbf{1 3 . 9 6 3 . 7 4 4}$ & $\mathbf{3 0 . 6 0 9 . 0 0 6}$
\end{tabular}

Sumber: Olahan Data Primer, 2015.

Berdasarkan hasil pada tabel 5, dapat diketahui bahwa biaya total responden usaha ternak ayam joper di Desa Bangun Harjo yang terdiri dari biaya tetap dan biaya variabel dalam satu kali proses produksi adalah sebesar Rp 13.963.744. Biaya total usaha ternak ayam broiler yang terdiri biaya tetap dan biaya variabel dalam satu kali proses produksi adalah sebesar Rp 30.609.006. Berdaarkan perhitungan diperoleh bahwa biaya total produksi usaha ternak ayam broiler lebih besar daripada biaya total usaha ternak ayam joper.

\section{B. Produksi, Harga, Penerimaan dan Pendapatan.}

Hasil akhir atau produksi dalam usaha ternak ayam joper adalah berupa ayam kampung yang dijual setelah 2 bulan masa pemeliharaan yabg dijual dalam bentuk per ekor ayam joper. Sedangkan produksi ternak ayam broiler adalah berupa daging ayam broiler yang dijual setelah 1 bulan pemeliharaan. Penerimaan usaha adalah nilai produk fisik dikalikan harga satuan yang diterima sebelum dikurangi dengan biaya-biaya. Pendapatan adalah penerimaan dikurangi dengan biaya produksi.

Tabel 6. Rata-rata Produki, Harga, Penerimaan dan Pendapatan Usaha Ternak Ayam Joper di Desa Bangun Harjo, 2015.

\begin{tabular}{rllr}
\hline No & Uraian & Satuan & Nilai (Rp/Proses) \\
\hline 1. & Produksi & Ekor/Proses & 573 \\
2. & Harga & Rp/Ekor & 40.000 \\
3. & Penerimaan & Rp/Proses & 22.920 .000 \\
4. & Biaya Total & Rp/Proses & 13.963 .744 \\
5. & Pendapatan & Rp/Proses & 8.956 .256
\end{tabular}

Sumber: Olahan Data Primer, 2015.

Berdasarkan hasil pada tabel 6, dapat diketahui bahwa rata-rata produksi ayam joper adalah sebanyak 573 Ekor/Proses. Rata-rata harga jual ayam joper adalah sebesar Rp 40.000/Ekor, sehingga dihasilkan rata-rata penerimaan sebesar Rp 22.920.000/Proses. Rata-rata total biaya produksi ternak ayam joper dalam satu kali 
proses adalah sebesar Rp 13.963.744 sehingga pendapatan yang diterima oleh pelaku usaha ternak ayam joper di Desa Bangun Harjo Kecamatan Buay Madang Timur dalam satu kali proses produksi adalah sebesar Rp 8.956.256.

Tabel 7. Rata-rata Produki, Harga, Penerimaan dan Pendapatan Usaha Ternak Ayam Broiler di Desa Bangun Harjo, 2015.

\begin{tabular}{rllr}
\hline No & Uraian & Satuan & Nilai (Rp/Proses) \\
\hline 1. & Produksi & $\mathrm{Kg} /$ Proses & 3.602 \\
2. & Harga & $\mathrm{Rp} / \mathrm{Kg}$ & 15.188 \\
3. & Penerimaan & Rp/Proses & 54.676 .250 \\
4. & Biaya Total & Rp/Proses & 30.609 .006 \\
5. & Pendapatan & Rp/Proses & 24.067 .244
\end{tabular}

Sumber: Olahan Data Primer, 2015.

Berdasarkan hasil pada tabel 7, dapat diketahui bahwa rata-rata produksi ayam broiler adalah sebanyak 3.602 Kg/Proses. Rata-rata harga jual ayam broiler adalah sebesar Rp 15.188/Kg, sehingga dihasilkan rata-rata penerimaan sebesar $\mathrm{Rp}$ 54.676.250/Proses. Rata-rata total biaya produksi ternak ayam broiler dalam satu kali proses adalah sebesar Rp 30.609.006 sehingga pendapatan yang diterima oleh pelaku usaha ternak ayam broiler di Desa Bangun Harjo Kecamatan Buay Madang Timur dalam satu kali proses produksi adalah sebesar Rp 24.067.244.

\section{Analisis R/C Rasio}

Tingkat keuntungan suatu analisis usaha dapat dinyatakan melalui $\mathrm{R} / \mathrm{C}$ rasion (return cost ratio) atau dikenal sebagai perbandingan antara penerimaan usaha dengan total biaya produksi. $\mathrm{R} / \mathrm{C}$ rasio digunakan untuk mengetahui rasio perbandingan keuntungan terhadap biaya produksi. Berikut adalah nilai R/C Rasio usaha ternak ayam joper di Desa Bangun Harjo.

Tabel 8. Nilai R/C Rasio Usaha Ternak Ayam

\begin{tabular}{rllr} 
& \multicolumn{3}{c}{ Joper di Desa Bangun Harjo, 2015.} \\
\hline No & Uraaian & Satuan & Nilai (Rpp Proses) \\
\hline 1. & Penerimaan & Rpp Proses & 22.920 .000 \\
2. & Biaya Total & Rpp Proses & 13.963 .744 \\
3. & Pendapatan & Rp/Proses & 8.956 .250 \\
4. & RC Rasio & & 1,64 \\
\hline
\end{tabular}

Sumber: Olahan Data Primer, 2015.

Berdasarkan hasil perhitungan pada tabel 8 diperoleh bahwa nilai $\mathrm{R} / \mathrm{C}$ rasio usaha ternak ayam joper diperoleh dari penerimaan dibagi dengan biaya produksi. Nilai R/C rasio usaha ternak ayam joper adalah sebesar Rp 1,64. Nilai $\mathrm{R} / \mathrm{C}$ rasio sebesar 1,64 artinya bahwa setiap satu rupiah biaya yang dikeluarkan untuk usaha ternak ayam joper maka akan menghasilkan penerimaan sebesar Rp 1,64. Nilai R/C > 1, menunjukkan bahwa usaha ternak ayam joper di Desa Bangun Harjo menguntungkan.

Tabel 9. Nilai R/C Rasio Usaha Ternak Ayam

\begin{tabular}{clcr}
\multicolumn{4}{c}{ Broiler di Desa Bangun Harjo, 2015. } \\
\hline No & Uraian & Satuan & Nilai (Rp/Proses) \\
\hline 1. & Penerimaan & Rp/Proses & 54.676 .250 \\
2. & Biaya Total & Rp/Proses & 30.609 .006 \\
3. & Pendapatan & Rp/Proses & 24.067 .244 \\
4. & R/C Rasio & & 1,79
\end{tabular}

Sumber: Olahan Data Primer, 2015.

Berdasarkan hasil perhitungan pada tabel 9, diperoleh bahwa nilai $\mathrm{R} / \mathrm{C}$ rasio usaha ternak ayam broiler diperoleh dari penerimaan usaha dibagi dengan biaya produksi. Nilai $\mathrm{R} / \mathrm{C}$ rasio usaha ternak ayam broiler adalah sebesar $\mathrm{Rp}$ 1,79. Nilai R/C rasio sebesar 1,79 artinya bahwa setiap satu rupiah biaya yang dikeluarkan untuk usaha ternak ayam broiler maka akan menghasilkan penerimaan sebesar $\mathrm{Rp} \mathrm{1,79}$. Nilai $\mathrm{R} / \mathrm{C}>1$, menunjukkan bahwa usaha ternak ayam broiler di Desa Bangun Harjo menguntungkan.

Berdasarkan hasil analisis diperoleh nilai $\mathrm{R} / \mathrm{C}$ rasio usaha ternak ayam joper adalah sebesar 1,64 dan nilai $\mathrm{R} / \mathrm{C}$ rasio usaha ternak ayam broiler adalah sebesar 1,79. Nilai R/C rasio usaha ternak ayam broiler lebih besar daripada nilai $\mathrm{R} / \mathrm{C}$ rasio usaha ternak ayam joper yang menunjukan bahwa usaha ternak ayam broiler di Desa Bangun Harjo Kecamatan Belitang OKU Timur lebih menguntungkan daripada usaha ternak ayam joper. D. Analisis BEP Harga dan BEP Produksi

Break Even Point (BEP) atau titik impas adalah suatu keadaan dimana usaha ternak ayam joper maupun ayam broiler dalam usahanya tidak memperoleh laba dan juga tidak menderita kerugian atau dengan kata lain total biaya sama dengan total penjualan sehingga tidak ada laba dan tidak ada rugi (impas).

Tabel 10. Nilai BEP Harga dan BEP Produki Usaha Ternak Ayam Joper dan Broiler di Desa Bangun Harjo, 2015.

\begin{tabular}{lllrr}
\hline \multirow{2}{*}{ No } & \multirow{2}{*}{ Komponen Biaya } & Satuan & \multicolumn{2}{c}{ Peternak } \\
\cline { 4 - 5 } & & & Ayam Joper & Ayam Broiler \\
\hline 1. & Produksi Daging & $(\mathrm{Kg} /$ Proses $)$ & 573 & 3.602 \\
2. & Harga Jual & $(\mathrm{Rp} / \mathrm{Kg})$ & 40.000 & 15.188 \\
3. & Penerimaan & (Rp/Proses) & 22.920 .000 & 54.676 .250 \\
4. & Biaya Produksi & (Rp/Proses) & 13.963 .744 & 30.609 .006 \\
5. & BEP Harga & (Rp/Proses) & 24.569 & 8.496 \\
6. & BEP Produksi & (Rp/Proses) & 349 & 2.017
\end{tabular}

Sumber: Olahan Data Primer, 2015. 


\section{BEP produksi}

BEP produksi menggambarkan jumlah produksi minimal daging ayam joper maupun broiler yang harus dihasilkan agar usaha tidak mengalami kerugian. Berdasarkan hasil analisis data pada tabel 10, diketahui bahwa nilai dari BEP produksi ayam joper adalah sebesar 349 ekor. Hal ini menunjukan bahwa pada saat produksi ayam joper mencapai 349 ekor maka usaha ternak ayam joper tidak untung dan tidak rugi. Berdasarkan hasil perhitungan diketahui bahwa nilai produksi ayam joper yang dihasilkan oleh responden ratarata adalah sebanyak 573 ekor sehingga diperoleh keuntungan 224 ekor ayam joper setiap produksi. Nilai produksi ayam joper yang lebih besar daripada nilai BEP produksi yang menunjukan bahwa usaha ternak ayam joper di Desa Bangun Harjo layak secara financial.

Berdasarkan hasil analisis data pada tabel 10, diketahui bahwa nilai dari BEP produksi daging ayam broiler adalah sebesar $2.017 \mathrm{Kg}$. Hal ini menunjukan bahwa pada saat produksi ayam broiler mencapai 2.017 ekor maka usaha ternak ayam broiler tidak untung dan tidak rugi. Berdasarkan hasil perhitungan diketahui bahwa nilai produksi daging ayam broiler yang dihasilkan oleh responden rata-rata adalah sebanyak $3.602 \mathrm{Kg}$ sehingga diperoleh keuntungan $1.585 \mathrm{Kg}$ daging ayam broiler setiap produksi. Nilai produksi ayam broiler yang lebih besar daripada nilai BEP produksi yang menunjukan bahwa usaha ternak ayam broiler di Desa Bangun Harjo layak secara financial.

\section{BEP Harga}

BEP harga menggambarkan harga terendah (harga minimal) dari penjualan ayam joper maupun broiler agar usaha tidak mengalami kerugian. Apabila harga yang dipasarkan lebih rendah dari BEP, maka usaha ini akan mengalami kerugian. Berdasarkan hasil analisis data maka diperoleh nilai dari BEP harga ayam joper $\mathrm{Rp}$ 24.569. Agar tidak mengalami kerugian maka harga jual ayam joper adalah sebesar Rp 24.569 per ekor. Berdasarkan hasil penelitian menunjukkan bahwa harga jual ayam joper di pasaran rata-rata adalah sebesar Rp 40.000/Ekor. Hal ini menunjukan bahwa harga jual ayam joper lebih tinggi daripada nilai BEP harga yang berarti usaha ternak ayam joper layak secara financial.

Berdasarkan hasil analisis data maka diperoleh nilai dari BEP harga ayam broiler Rp 8.406. Agar tidak mengalami kerugian maka harga jual ayam broiler adalah sebesar Rp 8.406 per Kg. Berdasarkan hasil penelitian menunjukkan bahwa harga jual ayam broiler di pasaran rata-rata adalah sebesar $\mathrm{Rp} 15.188 / \mathrm{Kg}$. Hal ini menunjukan bahwa harga jual ayam broiler lebih tinggi daripada nilai BEP harga yang berarti usaha ternak ayam broiler layak secara financial. Berdasarkan perhitungan BEP Harga dan BEP Produksi di atas dapat disimpulkan bahwa usaha ternak ayam joper dan ayam broiler di Desa Bangun Harjo Kecamatan Buay Madang Timur Kabupaten OKU Timur layak (feasibel) secara financial.

\section{IV.KESIMPULAN DAN SARAN}

\section{A. Kesimpulan}

Berdasarnya hasil penelitian dan analisis yang telah dilakukan, maka dapat ditarik kesimpulan sebagai berikut:

1. Biaya total produksi yang dikeluarkan dalam usaha ternak ayam joper di Desa Bangun Harjo dalam satu kali proses produksi adalah sebesar $\mathrm{Rp}$ 13.963.744, rata-rata penerimaan adalah sebesar Rp 22.920.000 sehingga pendapatan yang diterima adalah sebesar Rp 8.956.256. Nilai R/C rasio adalah sebesar 1,64 menunjukan bahwa usaha ternak ayam joper menguntungkan.

2. Biaya total produksi yang dikeluarkan dalam usaha ternak ayam broiler di Desa Bangun Harjo dalam satu kali proses produksi adalah sebesar Rp 30.609.006, rata-rata penerimaan adalah sebesar Rp 54.676.250 sehingga pendapatan yang diterima adalah sebesar $\mathrm{Rp}$ 24.067.224. Nilai R/C rasio adalah sebesar 1,79 menunjukan bahwa usaha ternak ayam broiler menguntungkan.

3. Nilai BEP volume produksi ternak ayam joper adalah sebesar 349 ekor, sedangkan nilai BEP harga adalah sebesar Rp 24.569/Ekor dan nilai BEP volume produksi ternak ayam broiler adalah sebesar $2.017 \mathrm{Kg}$, sedangkan nilai BEP harga adalah sebesar $\mathrm{Rp} 8.496 / \mathrm{Kg}$ yang menunjukkan bahwa usaha ternak ayam joper dan ayam broiler di Desa Bangun Harjo layak (feasible) secara finansial.

\section{B.Saran}

1. Hendaknya peternak ayam joper maupun ayam broiler dalam menjalankan usahanya tetap menjaga kebersihan dan sanitasi lingkungan.

2. Pemerintah melalui dinas atau instansi terkait diharapkan dapat memfasilitasi para peternak dalam hal akses permodalan pengembangan usaha, antara lain berupa : Kredit Usaha 
Rakyat (KUR), Kredit Usaha Mikro maupun kredit lainnya agar para peternak dapat mengembangkan usahanya.

\section{DAFTAR PUSTAKA}

Arikunto, Suharsimi. 2002. Prosedur Penelitian suatu Pendekatan Praktek. Rineka Cipta. Jakarta.

Ball. 2000. Bisnis Internasional. Salemba Empat. Jakarta.

Daniel, Mosher. 2002. Metode Penelitian Sosial Ekonomi di Lengkapi Beberapa Alat Dan Analisa dan Penuntut Pengguna. Jurnal Ilmi-ilmu Pertanian. Vol. 5, No 1, pp. 1-21

Effendy. (1998). Dasar-dasar kesehatan masyarakat. Jakarta: Penerbit Buku Kedokteran EGC

Hadisapoetra, S. 2003. Biaya Dan Pendapatan Di Dalam Usahatani. Departemen Ekonomi Fakultas Pertanian. UGM. Yogyakarta.

Umar, Husein. 2002. Metode Riset Bisnis. PT. Gramedia Pustaka Utama. Jakarta.

Ibrahim, Y. 2009. Study Kelayakan Bisnis. Rineka. Jakarta.
Kartasoepatra, A.G. 2006. Pengantar Ekonomi Produksi. Bina Aksana. Jakarta.

Linbong, W.H dan P. Sitorus, 2005. Pengantar Tata Niaga Pertanian. Jurusan Ilmu Social Ekonomi Pertanian. Institut Pertanian Bogor. Bogor

Muftiadi, A. Pengantar Ilmu Ekonomi. Kareka, Bandung.

Nuhfil, 2006. Strategi Pembangunan Pertanian. PT Bhratara Karya Aksara. Jakarta

Sjarkowi, F dan Sufri, M. 2004. Manajemen Agribisnis. CV Baldad Grafitti Press. Palembang ISBN : 979-96207-1-6.

Soekartawi. 2004. Prinsip Dasar Ekonomi Pertanian. Raja Grafindo Persada. Jakarta

Subagyo, A. 2007. Studi Kelayakan Teori dan Aplikasi. PT Elex Media Komputindo Jakarta

Sugiyono (2009), Metode Penelitian Bisnis, CV. Alfabeta, Bandung.

Suryana. 2006. Kewirausahaan, Pedoman Praktis, Kiat dan Proses Menuju Sukses. Edisi Revisi Salemba Empat. Jakarta.

Suwandi. 2008. Memahami Penelitian Kualitatif. Rineka Cipta. Jakarta. 